\title{
In vitro Root Development System in Two Popular Cultivars of Banana
}

\author{
Mulugeta Gobena, Sunil T. Hajare* and Girmaye Benti \\ Department of Biology, College of Natural and Computational Sciences, \\ Dilla University, Dilla 419, Ethiopia
}

*Corresponding author

\section{Keywords \\ In vitro rooting, PGR, Musa spp, Poyo, Grand naine, IBA, NAA}

\section{Article Info}

Accepted: 26 July 2017 Available Online: 10 January 2018

\section{A B S T R A C T}

Banana is one of the most important and remunerative cash crops grown round the year in Ethiopia. The energy and nutritional status of banana are much higher than other common tropical and subtropical fruits. The objective of this study was to establish in vitro root development protocol in Poyo and Grand naine varieties from sucker. For root induction suckers of Poyo and Grand naine were cultured on MS basal medium that contained $30 \mathrm{~g} / \mathrm{l}$ sucrose, $6 \mathrm{~g} / \mathrm{l}$ agar and vitamins. Rooting of the shoots was done on full strength MS basal medium supplemented with different concentrations of IBA $(0.5,1.0,1.5,2.0 \mathrm{mg} / \mathrm{l})$ and NAA in sole and in combination $(0.5 \mathrm{mg} / \mathrm{l} \mathrm{IBA}+0.5 \mathrm{mg} / \mathrm{l} \mathrm{NAA}$ and $1.0 \mathrm{mg} / \mathrm{l} \mathrm{IBA}+1.0$ mg/l NAA). In all cases, MS basal medium without PGRs was used as control. The rooted plantlets were then acclimatized under greenhouse conditions by transplanting the plantlets on moist red soil, sand soil and compost or their mixture in 2:1:1 ratio. Results showed that root formation responses were significantly $(\mathrm{P}<0.05)$ higher under all levels and combinations of hormones when compared with control treatments. For Poyo variety, $0.5 \mathrm{mg} / \mathrm{l} \mathrm{IBA}$ had higher response for root numbers and root length than at other treatments. Number of days to root emergence was found to be shorter at $20 . \mathrm{mg} / \mathrm{l}$ NAA of hormonal level than other treatments. In the case of Grand naine variety, the concentration of $1.5 \mathrm{mg} / 1$ IBA alone treatment had positive effects on multiple root formation and $\mathrm{MS}+0.5 \mathrm{mg} / \mathrm{l}$ IBA for highest length of roots. The number of days for root emergence was found to be shorter at combination of $1.0+1.0 \mathrm{mg} / \mathrm{l} \mathrm{IBA}$ and NAA in grand naine. Compared to the control, both IBA and NAA alone or in combination showed significant positive effect on root formation of shoots of both varieties. The acclimatization experiment showed that plantlets of both varieties survived better on the sterilized mixture of moist red soil, sand and compost soil in a ratio of 2:1:1. Comparison of the performance of both varieties showed that Poyo showed superior performance compared to Grand naine variety with respect to all measured agronomic traits except field survival rate which found better in grand naine, suggesting that varietal difference for the difference in the response to the PGRs. 


\section{Introduction}

In Ethiopia, as in many parts of the tropical and subtropical developing world, banana is a highly important food crop. However, in the last 20 years, there was a rapid decline in banana production due to widespread of soil degradation and the infestation of banana orchards with pests and diseases. These problems were further aggravated by the common practice of propagating new banana plants using infected suckers. The situation was threatening food security, employment and incomes in banana producing areas. Tissue culture technology is considered worldwide an appropriate option to provide sufficient quality and quantity of such materials (Fanos Mekonnen et al., 2014).

Now a day, although banana plantation is widely spreading in Ethiopia, its quantity and quality are affected by number of biotic and abiotic factors. Its production is threatened by various foliar diseases, nematodes, viruses, and insect pests. Virus diseases are the major problems of banana plantation throughout world including Ethiopia. The impact of these factors is highly affecting the livelihood of poor marginal small-scale farmers (Seifu, 2003). In most parts of the country, production of banana has yet been limited to backyard and small-scale productions.

The report of CSA, (2014) and FAOSTAT, (2012) indicated the average productivity of banana in Ethiopia is 5-8.95 tons/ha, which is far below the world average 15.8 tons/ha. Lack of improved varieties is one of the critical factors that affect its production and productivity in Ethiopia (Tekle et al., 2014).

Since almost all the cultivated or edible banana cultivars are triploid, seedless, or seed sterile, banana is propagated vegetatively. Beside carrying weevils, fungal pathogens, nematodes, and viruses, the materials used for conventional propagation suffer from slow multiplication, bulkiness, and poor phytosanitary quality (Sagi, et al., 1998). The productivity of banana is highly reduced by transmission of insect pests and diseases caused by the farmer produced suckers as well as the application of high quantities of pesticides that result in additional cost of production and serious consequences for the environment. In general, the traditional clonal propagation method is unable to supply the increasing demand for disease free and healthy planting materials of banana.

According to Lepoivre (2000), virus diseases are major productivity limitations for vegetatively propagated bananas. Therefore, it is crucial to investigate and adopt alternative propagation method of banana that ensures disease free and healthy planting materials. To improve the present scenario, tissue culture technology could be best alternative which can provides rapid and large scale planting material (Stover and Simmonds, 1987).

In micropropagation, rooting of microcuttings is often problematic due to unmatched combination of auxins. Losses at this stage have vast economic consequences. In conventional propagation via cutting, many genotypes are also found weak in formation of roots (Hazarika et al., 2006). Thus research on strong root development in vitro is highly needed. At same time, strong root formation fascinating scientific subject matter.

Critical prerequisites in the development of banana include efficient and reproducible plant regeneration systems and a successful acclimatization process of tissue cultural plants for field transfer (Sagi et al., 1998). The two major problems faced in developing tissue cultural banana plants are low rooting efficiency of regenerated shoots and low acclimatization rate of rooted in vitro raised plants in the field. These problems could probably be due to poor quality roots such as 
thickened, callused, and absent lateral roots and root hairs formation, which all affect the uptake of nutrients by the plants after transfer into soil. Therefore, rooting efficiency and quality roots formation are critical in ensuring successful and continuous production of tissue cultural banana. Indole-3-butyric acid (IBA) had been reported by many researchers as the best auxin for root induction in banana at an optimum concentration of $10 \mu \mathrm{M}$. IBA was known to have greater ability to promote rooting with less callus formation (Stickens et al., 1996). Numerous authors reported that rooting in agar medium produced thick, short, and stumpy roots. Many authors reported that vermiculite was able to improve rooting efficiency and produce good quality roots which were finer with abundant lateral branches and root hairs (Singh, and Shetty, 2011).

Based upon these studies which reported positive effects of auxin on rooting in banana outside of the Ethiopia, an effort had been made to improve rooting in most popular commercial cultivars of Ethiopia i.e., Poyo and Grand Naine which was need of hour.

Micropropagation has been widely used for rapid mass multiplication of banana; however, its application on commercial scale is restricted often due to high rate of plant loss when transferred to natural or ex vitro conditions due to weak rooting (Hartman et al., 1990).

Every technology has some limitations; Tissue culture technology is not exception to it. However, success at commercial scale is constrained by formation of aberrant plantlets and low survival of the regenerate during transfer to field conditions.

The major problem in field survival of tissue culture raised plantlets is due to poor in vitro rooting. Crops with root problems usually have irregular growth and flowering resulted in to huge economic loss to the farmers especially small-scale farmers (Gaspar et al., 1996; Sahay and Verma, 2000; Bairu and Kane, 2011).

Considering this prelude the present study was undertaken with specific objective to determine the effect of different combination and concentrations of Auxins (ABA and NAA) on root initiation, root numbers, root length and survival rate of in vitro raised plantlets of two banana varieties.

\section{Materials and Methods}

The experimental material comprised of three banana cultivars Viz. Poyo and Grand naine. From each cultivar sucker was used as explant for in vitro rooting.

The suckers of banana (Musa spp.) cv. Poyo and grand naine (Collected from Areka tissue culture centre) were treated with $70 \%$ cetrimide for $5 \mathrm{~min}$, rinsed thoroughly with double distilled water followed by treatment with $70 \%$ ethanol for $5 \mathrm{~min}$ and $0.1 \%$ mercuric chloride solution for $5 \mathrm{~min}$.

Finally the suckers were washed 5-6times with sterile double distilled water under aseptic conditions

\section{Elongation of shoots}

The adventitious buds/multiple shoot induced from the explants were excised from the bunch without any callus or globular structures and cultured on the shoot elongation medium (SEM), consisting of MS medium supplemented with BAP and Kinetin.

\section{Rooting}

The elongated shoots were transferred to rooting medium with varying concentrations of IBA and NAA in sole and in combination. After appropriate sub culturing, well grown 
shoots were aseptically transferred for root induction in the culture jars treated with five levels $(0.0 \mathrm{mg} / 1,0.5 \mathrm{mg} / 1,1.0 \mathrm{mg} / 1,1.5 \mathrm{mg} / \mathrm{l}$ and $2.0 \mathrm{mg} / \mathrm{l})$ of IBA and NAA.

Their combination (IBA+NAA) was taken in arrangements (i.e. IBA $0.5 \mathrm{mg} / \mathrm{l}+\mathrm{NAA} 0.5 \mathrm{mg} / \mathrm{l}$ and IBA1.0mg/l+NAA1.0mg/l). The combine effects of auxins with minimal concentration on rooting of banana have been recorded by many researchers (Tilkat, 2009; Arias, 1992). Finally all these were incubated at $25 \pm 2^{\circ} \mathrm{C}$ temperature and photoperiodic cycle of 16 hours with light intensity. In this step there were total of 10 treatments for each banana variety ten cultured tubes for each. The number of cultured tubes in each round was 200 (10 treatments $\times 2$ vareities $\times 10$ culture tubes).

\section{Transplantation}

After six weeks the plantlets were taken out, roots were washed thoroughly with tap water and transferred to small earthen pots filled with potting mixture consisting of garden soil, sand and bio-manure (Green house, Areka Tissue culture laboratory) in equal proportion. Each pot with plantlet was initially covered with transparent polythene bag for 5 days. However, after 2 days the corners of the polythene bags were cut.

Subsequently, the polythene bags were removed. After allowing the plants to grow further for another 6 days, the plants were carefully transferred to large earthen pots (30 $\mathrm{cm}$ diameter $\times 37.5 \mathrm{~cm}$ height) having garden soil, sand and bi-manure in equal proportion. After two weeks the plantlets were transferred to field and survival rate was measured after 4 weeks.

\section{Statistical analysis}

All the quantitative data analysis was done by using excel spread sheet, recorded for all responses were subjected to two-way Analysis of variance (ANOVA) and significant differences among treatments were determined by Fisher's Least Significance Difference (LSD) at 5\% level of significance by using the SAS (Version 9.2) software package for the differentiation of the effect of treatment, genotype and treatment-genotype interaction.

\section{Results and Discussion}

Effect of different concentrations of auxins (IBA and NAA) in sole and combination on in vitro root induction and duration of root initiation culture in Poyo variety

Highest numbers of roots (7.3 and 8.7) were observed on the medium supplemented with $0.5 \mathrm{mg} / \mathrm{l} \mathrm{BAP}$, while in the control medium produced 2.1 and 2.8 roots/plant after 18 days and 36 days of inoculation, respectively (Table 1 and Fig. 2). These results are in agreement with the findings of Molla et al., (2004) who obtained 8.28 maximum numbers of roots (8.28 / plant) on $0.5 \mathrm{mg} / \mathrm{l}$ IBA followed by 6.33 roots, on $0.6 \mathrm{mg} / \mathrm{l} \mathrm{IBA}$. It indicates increasing concentration of IBA doesn't in favor of rooting. The results of current investigation also in line with the findings of Gubbuk and Pekmezci (2001) who obtained 8.28 roots per plantlet on MS medium fortified with $0.5 \mathrm{mg} / \mathrm{l} \mathrm{IBA}$.

On the MS Medium provided with NAA, the highest numbers of roots (4.2 and 6.5/ plant) were recorded at the concentration $1.0 \mathrm{mg} / \mathrm{l}$ NAA, while the significantly low number of roots 1.3 and 2.1 recorded in the control group after 18 days and 36 days of inoculation, respectively (Table 1). These results are similar with the findings of Anbazhagan et al., (2014) who recorded maximum number of roots (6.1/ plant) on the MS medium augmented with $1.0 \mathrm{mg} / \mathrm{l}$ NAA. The number of roots/plant received in current investigation also comparable with 
Viehmannova et al., (2007) who recorded maximum number of roots (14.79 roots /plant) on MS media supplemented with $5.4 \mu$ M NAA (which is equivalent to $1.0 \mathrm{mg} / \mathrm{l}$ ).

The results are also commensurate with the findings of Sazedur et al., (2013) who stated, $1.0 \mathrm{mg} / \mathrm{l} \mathrm{NAA}$ best for rooting in the $\mathrm{cv}$. Agnishwar. The results also found in line with the findings of Rout G (2004) and Habib (1994) who reported superiority of NAA over other auxins in root development in vitro

Table.1 Effect of different concentrations of auxins (IBA and NAA) in sole and combination on in vitro root induction culture in Poyo variety

\begin{tabular}{|c|c|c|c|c|c|}
\hline \multirow{2}{*}{$\begin{array}{c}\text { Type of } \\
\text { growth } \\
\text { Regulator }\end{array}$} & $\begin{array}{c}\text { Concentra } \\
\text { tion } \\
\text { In mg/l }\end{array}$ & \multicolumn{2}{|c|}{$\begin{array}{c}\text { Number of roots 18 days after the } \\
\text { inoculation }\end{array}$} & \multicolumn{2}{c|}{$\begin{array}{c}\text { Number of roots 36 days after the } \\
\text { inoculation }\end{array}$} \\
\cline { 2 - 6 } & Number of roots & Std. Error & Number of roots & Std. Error \\
\hline \multirow{4}{*}{$\begin{array}{c}\text { MS } \\
+\end{array}$} & 0.0 & 2.1000 & .32240 & 2.8000 & .25517 \\
\cline { 2 - 6 } IBA & 0.5 & 7.3000 & .96575 & 8.7000 & 1.09128 \\
\cline { 2 - 6 } & 1.0 & 5.3000 & .52451 & 7.2000 & .98601 \\
\cline { 2 - 6 } & 1.5 & 4.5000 & .44020 & 6.8300 & .84064 \\
\cline { 2 - 6 } & 2.0 & 3.2000 & .46092 & 4.1700 & .62112 \\
\hline \multirow{2}{*}{$\begin{array}{c}\text { MS } \\
+\end{array}$} & 0.0 & 1.3000 & .27162 & 2.1000 & .35214 \\
\cline { 2 - 6 } & 0.5 & 3.6000 & .54549 & 4.8000 & .40056 \\
\cline { 2 - 6 } & 1.0 & 4.2000 & .49643 & 6.5000 & .52557 \\
\cline { 2 - 6 } & 1.5 & 3.5200 & .39038 & 4.9000 & .52831 \\
\cline { 2 - 6 } & 2.0 & 3.3000 & .44944 & 4.5000 & .54732 \\
\hline \multirow{2}{*}{ MS+ } & $0.5+0.5$ & 5.5000 & .86049 & 8.6000 & .64274 \\
\cline { 2 - 6 } & $1.0+1.0$ & 4.3000 & .40661 & 6.9000 & .56431 \\
\hline
\end{tabular}

Table.2 Effect of different concentrations of auxins (IBA and NAA) in sole and combination on in vitro root induction culture in Grand naine variety

\begin{tabular}{|c|c|c|c|c|c|}
\hline \multirow{2}{*}{$\begin{array}{c}\text { Type of } \\
\text { growth } \\
\text { Regulator }\end{array}$} & $\begin{array}{c}\text { Concentration } \\
\text { In mg/l }\end{array}$ & \multicolumn{2}{|c|}{$\begin{array}{c}\text { Number of roots 18 days after the } \\
\text { inoculation }\end{array}$} & $\begin{array}{c}\text { Number of roots 36 days after the } \\
\text { inoculation }\end{array}$ \\
\cline { 2 - 6 } & & Number of roots & Std. Error & Number of roots & Std. Error \\
\hline \multirow{3}{*}{$\begin{array}{c}\text { MS } \\
+\end{array}$} & 0.0 & 3.7500 & .50602 & 4.9000 & .73409 \\
\cline { 2 - 6 } IBA & 0.5 & 4.0000 & .41096 & 5.5000 & .62414 \\
\cline { 2 - 6 } & 1.0 & 4.7500 & .50668 & 6.2500 & .57701 \\
\cline { 2 - 6 } & 1.5 & 5.2500 & .57528 & 6.8500 & 1.06011 \\
\cline { 2 - 6 } & 2.0 & 3.5500 & .43211 & 4.6500 & .78206 \\
\hline \multirow{3}{*}{$\begin{array}{c}\text { MS } \\
\text { NAA }\end{array}$} & 0.0 & 1.3000 & .26119 & 2.0400 & .32971 \\
\cline { 2 - 6 } & 0.5 & 2.0800 & .33856 & 3.6900 & .47550 \\
\cline { 2 - 6 } & 1.0 & 3.4700 & .37625 & 3.9000 & .50022 \\
\cline { 2 - 6 } & 1.5 & 3.1600 & .49826 & 3.7000 & .34928 \\
\hline MS+ & 2.0 & 2.8900 & .47410 & 3.3900 & .49294 \\
\cline { 2 - 6 } IBA+NAA & $1.5+0.5$ & 3.2500 & .50755 & 3.5000 & .34319 \\
\hline \multirow{2}{*}{} & & 2.1500 & .29411 & 2.8500 & .34681 \\
\hline
\end{tabular}


Int.J.Curr.Microbiol.App.Sci (2018) 7(1): 3583-3591

Plate.1 Preparation of Explant and Shoot elongation
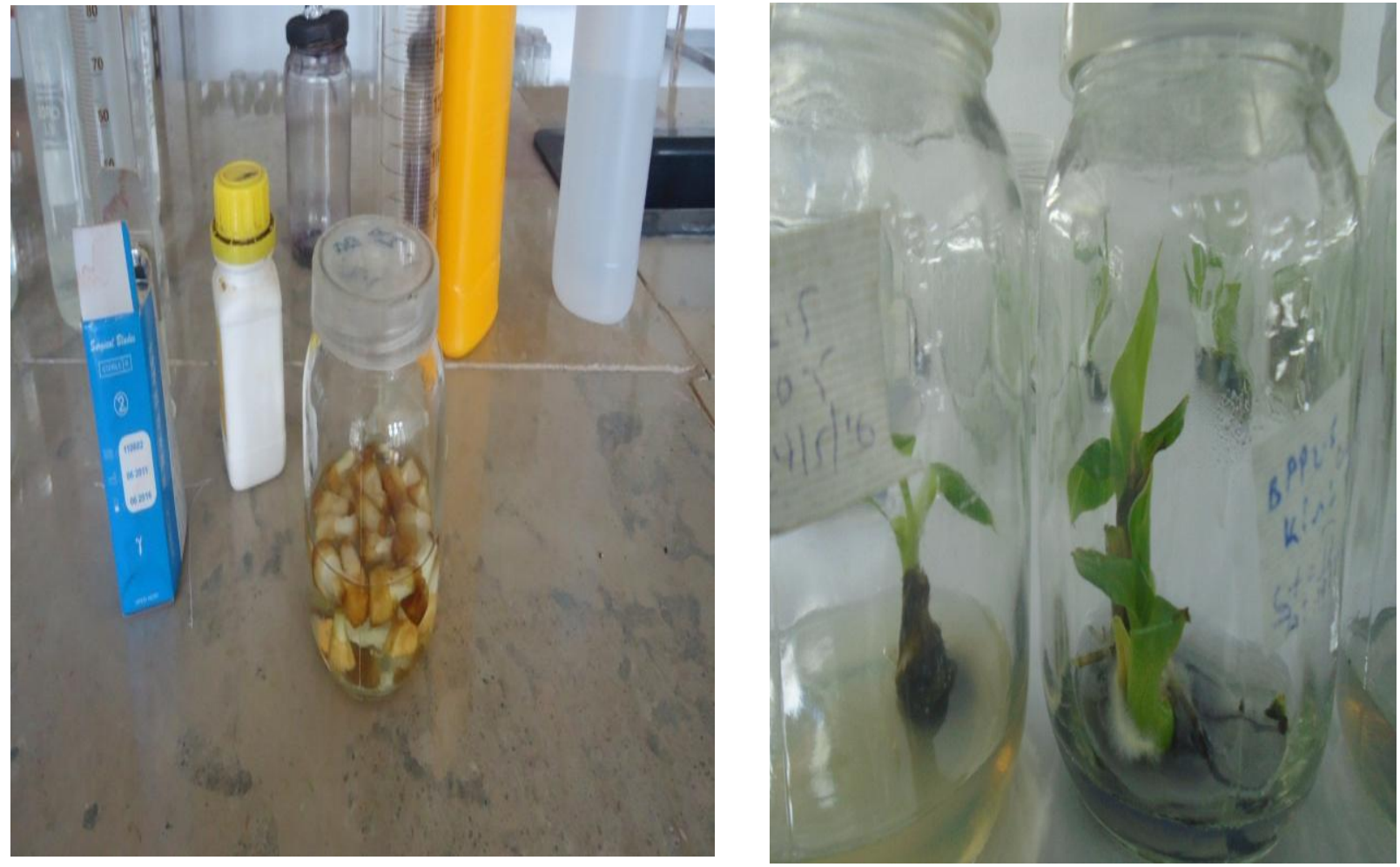

Plate.2 Rooting after 18 days
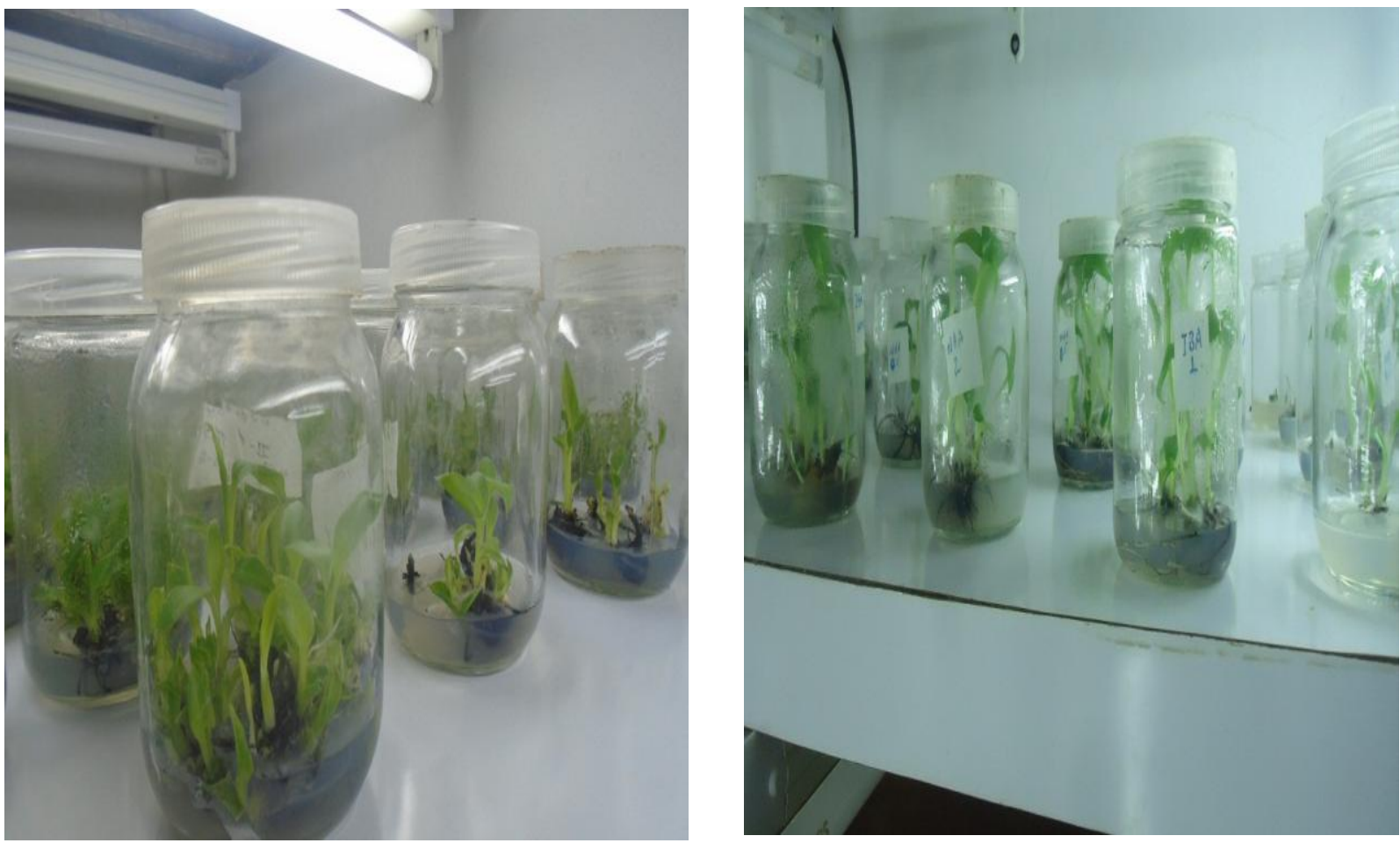
Plate.3 Rooting after 36 days

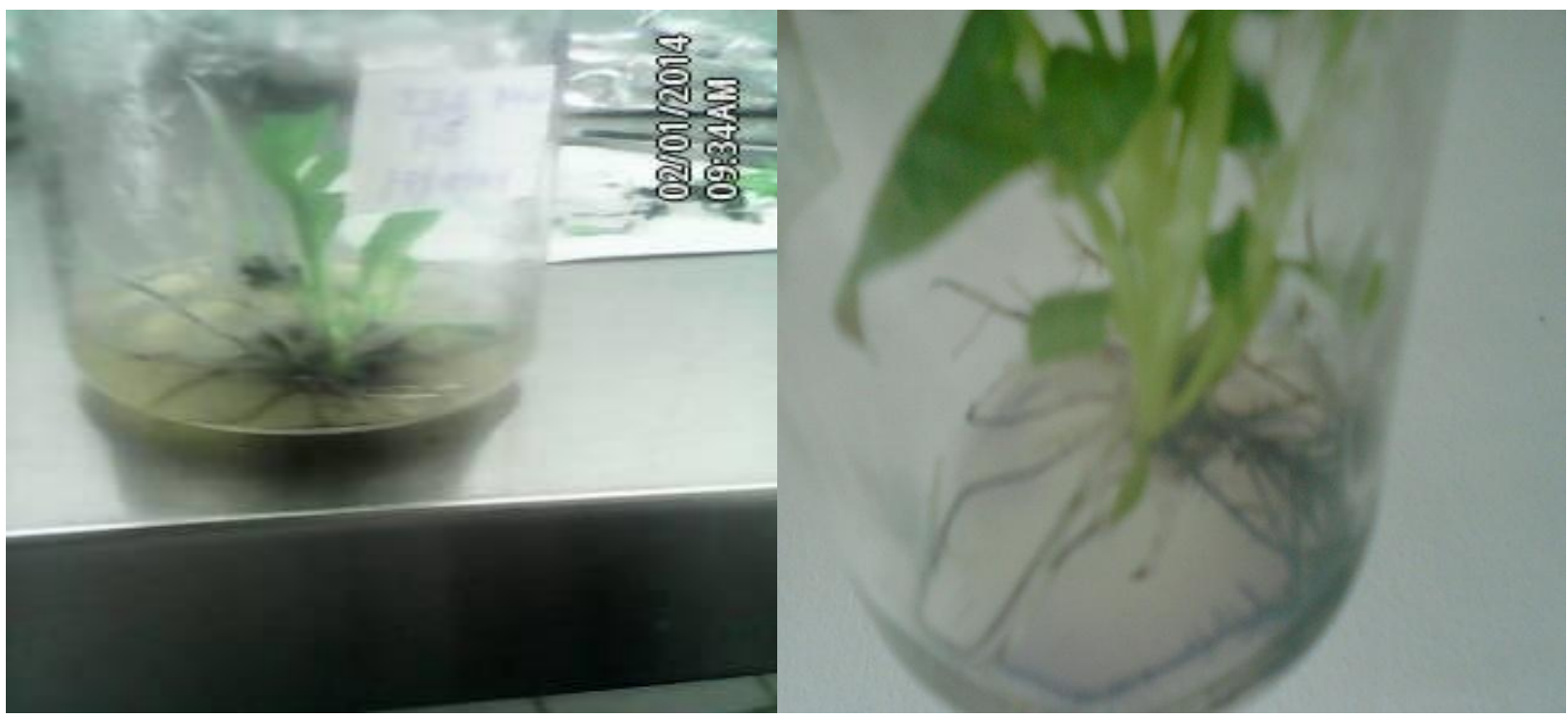

Effect of different concentrations of auxins (IBA and NAA) in sole and combination on in vitro root induction in Grand naine variety

In Grand Naine, the maximum number (5.25 and 6.85) and the minimum (3.55 and 4.65) roots/ plant were observed in the MS media supplemented with $1.5 \mathrm{mg} / \mathrm{l} \mathrm{IBA}$ and $2.0 \mathrm{mg} / \mathrm{l}$ IBA after $18^{\text {th }}$ and $36^{\text {th }}$ days of the inoculation, respectively (Table 2 and Fig. 2). Similar result reported by Million et al., (2013) that IBA $1.5 \mathrm{mg} / \mathrm{l}$ produced maximum number of roots 5.1 and 7.1 in 15 and 30 days. But in contrast with Shahanawaz et al., (2014) who reported maximum rooting on MS medium of half strength supplemented with IBA $1.0 \mathrm{mg} / \mathrm{l}$ and activated charcoal 200mg/l.

This might be because of difference in temperature, banana variety and strength of the MS media used. As per the Gubbuk H, (2004) continued rhizogenises is influenced by sugar, Auxin, temperature and light.

The MS medium with NAA, produced (3.47 and 3.90) roots/plant. Whereas, poor response was observed with least number of roots (1.3and 2.04) on MS media added with $1.0 \mathrm{mg} / \mathrm{l}$ NAA and the control media respectively (Table 2 and Fig. 2). Similar result was reported by Anbazhagan et al., (2014) with the maximum number of roots 3.4 using NAA at the concentration $1.0 \mathrm{mg} / \mathrm{l}$.

The MS medium with combination of IBA and NAA produced maximum number of (3.25 and 3.5) root/plant with the combination of $\quad 0.5 \mathrm{mg} / \mathrm{l} \quad \mathrm{IBA}+0.5 \mathrm{mg} / \mathrm{l} \quad \mathrm{NAA}$ and $1.0 \mathrm{mg} / \mathrm{IBA}+1.0 \mathrm{mg} / \mathrm{l} \mathrm{NAA}$ after $18^{\text {th }}$ and $36^{\text {th }}$ days of inoculation, respectively (Table 2 and Fig. 2). This results are in agreement with Arun et al.,(2012), who reported 4.56 and 2.30 roots $/$ plant on $0.5 \mathrm{mg} / 1 \mathrm{IBA}+0.5 \mathrm{mg} / \mathrm{l}$ $\mathrm{NAA}$ and $1.0 \mathrm{mg} / \mathrm{l}$ IBA+1.0mg/l NAA fortified MS medium respectively. However, the appropriate amount of auxin in the rooting medium is crucial for the induction of the root (Arias 1992; Arinaitwe et al., 2000).

\section{The overall percentage of rooted shoots}

The percentages of rooting/ shoots were counted from all treatment tested in the two banana varieties. The MS medium fortified with BAP produced $60,80,80,80$, and $70 \%$ 
in Poyo and 50, 70, 80, 90 and $70 \%$ in the Grand naine with $0.0,0.5,1.0,1.5$ and $2.0 \mathrm{mg} / \mathrm{l}$ concentration. On the other hand plantlets taken from MS medium supplemented with NAA showed the survival rates of 50, 70, 70, 80 and 90\% in Poyo and $40,60,60,70$ and $90 \%$ in Grand naine at 0.0 , $0.5,1.0,1.5$ and $2.0 \mathrm{mg} / \mathrm{l}$ concentration, respectively. This shows that there is direct proportionality between increase in concentration of growth regulators and the percentage of rooted shoots. These result confirms the previous finding with Sazedur $e t$ al., (2013) who achieved 83, 96 and 88\% survival of the plantlets taken from MS medium added with $0.5,1.0$ and $2.0 \mathrm{mg} / \mathrm{IBA}$ and 67,76 and $79 \%$ as percentage of rooted shoots in $0.5,1.0$ and $2.0 \mathrm{mg} / 1$ NAA.

Rapid propagation of banana planting material through sucker culture ensures quick availability of genetically uniform (true to type) diseases free planting materials within short period of time. In the present study, an effective protocol for root development from sucker as explants was developed for two banana varieties Poyo and Grand naine. Accordingly, irrespective of the type of carbon source 3\% sucrose used in the MS solid medium, the concentration of $0.5 \mathrm{mg} / \mathrm{l}$ IBA was found to be the best for root induction and root length for varieties Poyo, while the $2.0 \mathrm{mg} / \mathrm{l} \mathrm{NAA}$ found to be the best for quick ignition of rooting in both cultivars tested. The combination $0.5 \mathrm{mg} / \mathrm{l} \mathrm{IBA}+0.5$ $\mathrm{mg} / \mathrm{l} \mathrm{NAA}$ and $1.0 \mathrm{mg} / \mathrm{l} \mathrm{IBA}+1.0 \mathrm{mg} / \mathrm{l} \mathrm{NAA}$ fail to produce promising results for Poyo.

Whereas the combination of IBA and NAA $(1.0 \mathrm{mg} / \mathrm{l}$ each) found best for quick root induction in grand naine but fail to produce multiple roots. The concentrations of IBA 1.5 and $0.5 \mathrm{mg} / \mathrm{l}$ found best for multiple rooting and highest length of roots, respectively in grand naine.
The survival rate was recorded highest in the plantlets which were taken or raised in MS medium with $2.0 \mathrm{mg} / \mathrm{l} \mathrm{IBA}$ and $2.0 \mathrm{mg} / \mathrm{l}$ NAA.

\section{References}

Anbazhagan, B., Balachandran, and Arumugam, K. 2014.In vitro micropropagation of banana International journal of current Microbiology and applied science. ISSN: 2319-7706 Volume 3 Number 7(2014) Pp.399-404.

Arias, O., 1992. Commercial micro propagation of banana. In: Biotechnology Applications for Banana and Plantain Improvement. Inibap, San Jose, Costa Rica. Pp. 139-142.

Arias, O., 1992. Commercial micro propagation of banana. In: Biotechnology Applications for Banana and Plantain Improvement. Inibap, San Jose, Costa Rica. Pp. 139-142.

Arinaitwe, C., Rubaihayo, P. and Magambo M. 2000.Proliferation rate effects of cytokinin on banana (Musa spp.) cultivars. Scientia Horticulturae 86, 13-21.

Arun, K., Pingal K. and L.N. Shukla, 2012.Indian J. Innovations Dev. In vitro rooting in the tissue culture raised plantlets of Malbhog cultivar of Banana. Vol.1,No.9. Pp. 665667.

Bairu, M., and Kane M. 2011a. Physiological and developmental problems encountered by in vitro cultured plants. Plant Growth Regulation63: 101-103

CSA, 2014. Agricultural Sample Survey. Report on Area and Production of Major Crops. Volume I, VII and VIII. Statistical Bulletin 578. Addis Ababa, Ethiopia.

Fanos Mekonnen, 2014. Zonal diagnosis and intervention plan West Shoa, Oromia.

FAOSTAT, 2012. Overview of World Banana Production and Trade. The World Banana Economy, 1985-2012.

Gaspar, T., Bisbis, B, and Kevers C, 1998. A typical metabo-lisms and biochemical cycles imposing the cancerous state on plant cells. Plant Growth Regulation24:135-144

Gubbuk, H., and Pekmezci, M. 2001.The effects of different hormone types and 
concentrations on propagation of different banana clones by meristem culture. Ziraat Fakultesi Dergisi, Akdeniz Universitesi. 14(1): 127-137.

Gubbuk, H., and Pekmezci, M. 2004. In vitro Propagation of Some New Banana Types (Musa spp.). Turkish Journal of Agriculture and Forestry. 28, 355-361.

Habib, A., 1994. Mass propoagation of Musa sapientum var. sagar and performance of different genotype of Musa Cavendish (Grand Naine) in Bangladesh.M.Sc Thesis, University of Dhaka, Pp53-54.

Hartman, H.T., D.E. Kester and F.T. Davis. 1990. Plant propagation: Principles and practices. Prentice/Hall International, Inc. Englewood Cliffs, New Jersey

Hazarika, B., 2006.Morpho-physiological disorders in in vitro culture of plants. SciHortic 108:105-120.

Lepoivre, P., 2000. Banana in vitro regeneration: Virus eradication. Laboratory of Plant Pathology, University of Gembloux, Belgium, Pp. 22.

Rout, G., 2004. Effect of cytokinins and auxin on micropropagation of Clitoriaternatea $\mathrm{L}$. Biol. Lett. 41(1): 21-26.

Sagi, L., Gregory, D. Remy, S. and R. Swennen. 1998. Recent developments in biotechnological research on bananas (Musa spp.). Biotechnology. Genetic.Rev. 15: 313-317.

Sahay, N., and Varma A. 2000. A biological approach towards increasing the rates of survival of micropropagated plants. Current Science 78: 126-129

Sazedur, R., Nirupam, B., Mehedi, H. and Golam, A., 2013. International Research Journal of
Biotechnology. Micro propagation of banana (Musa sp.) cv. Agnishwar by In vitro shoot tip culture. Vol. 4(4) pp. 83-88.

Seifu, G., 2003. Status of Commercial Fruit Production in Ethiopia.Ethiopia Agricultural Research Organization, Addis Ababa, Ethiopia.

Shahnawaz, A., Akash, S., Singh, A., Wali, V. and Preeti, K. 2014. In vitro multiplication of banana (Musa sp.) cv. Grand Naine. African J. of Biotechnol 13(27): 2696-2703.

Singh, G., and Shetty, S. 2011.Impact of Tissue Culture on Agriculture in India. Society for Applied Biotech.1 (2):147-188.37.

Stickens, D., Tao, W. and Verbelen, J. 1996.A single cell model system to study hormone signal transduction. Plant Growth Regul. $18,149-154$.

Stover, R., and Simmonds, N. 1987. Bananas, Longman Scientific and Technical, Essex, UK.

Tekle, Y., Wondewosen, S., Zemach, S., Tibebu, S., Abraham, S., Woineshet, S. 2014. Adaptability Study of banana (Musa paradisiacal var. sapiertum) varieties at Jinka, Southern Ethiopia. American Journal of Agriculture and Forestry. Vol.2. No. 6, Pp. 250-255.

Tilkat, E., Onay, A., Yildirim, H. and Ayaz, E. 2009. Direct plant regeneration from mature leaf explants of pistachio, Pistaciavera L. Scientia Hort. 121(3): 361365.

Viehmannovai, F., Hnilickaf, E. and Roblesc, D.2007. Agricultura Tropica ET Subtropica. The influence of growth regulators on root induction in-vitro of the musa genus vol. 40(3) p 115-117.

\section{How to cite this article:}

Mulugeta Gobena, Sunil T. Hajare and Girmaye Benti. 2018. In vitro Root Development System in Two Popular Cultivars of Banana. Int.J.Curr.Microbiol.App.Sci. 7(1): 3583-3591. doi: https://doi.org/10.20546/ijcmas.2018.701.420 